\title{
Desain Sepeda Rotan dengan Rekayasa Material Rotan Resin
}

\author{
Arie Kurniawan, Agus Windharto dan Nur Ameliyah Rizkiyah \\ Departemen Desain Produk, Fakultas Desain Kreatif dan Bisnis Digital, \\ Institut Teknologi Sepuluh Nopember, Surabaya, Indonesia \\ e-mail:ariekrnwn@gmail.com
}

\begin{abstract}
Abstrak - Upaya pemerintah Indonesia dalam meningkatkan daya saing rotan adalah mengarahkan pengembangan produk rotan pada produk yang menyangkut gaya hidup masyarakat. Salah satu produk yang menjadi konsumsi gaya hidup dan tidak pernah mati adalah sepeda. Rancang bangun dan prototyping sepeda rotan adalah salah satu inovasi dan kontribusi peningkatan daya saing material rotan. Rotan belum diujicoba sebagai struktur sepeda sedangkan utilitas sepeda tergantung pada struktur pembentuk rangka. Permasalahan yang terjadi pada saat menggunakan material rotan sebagai struktur rangka sepeda adalah kekuatannya. Oleh karena itu perlu strategi dalam desain rangka sepeda berbahan rotan. Dalam proses desain rangka sepeda sebagai struktur diperlukan strategi dalam : penentuan geometri sepeda, rekayasa material rotan batang dan sambungan struktur rangka rotan. Metode uji eksperimen material dilakukan dengan uji laboratorium guna mengetahui peningkatan kualitas rotan. Hasil dari penelitian ini menyebutkan bahwa untuk geometri sepeda disesuaikan dengan utilitasnya, sedangkan strukturnya lebih baik menggunakan struktur tertutup rotan batang. Untuk rekayasa material rotan penggunaan resin infusion terbukti dapat meningkatkan kekuatan batang rotan hingga lima kali lipat. Beberapa bagian dari rangka sepeda tetap menggunakan sambungan metal sebagai pengunci struktur sehingga struktur rotan dapat menjadi kontruksi yang baik pada desain sepeda.
\end{abstract}

Kata Kunci-Desain sepeda, infus rotan, rangka rotan, struktur rangka

\begin{abstract}
Indonesian government in improving the competitiveness of rattan are to direct the development of rattan products on products that involve the lifestyle of the community. The product that is a lifestyle consumption and never dies is a bicycle. The design and prototyping of rattan bikes is one of the innovations and contributions to increase the competitiveness of rattan materials. Rattan has not been tested as a bicycle structure while bicycle utilities depend on the frame-forming structure. The problem that occurs when using rattan material as a bicycle frame structure is its strength. Therefore we need a strategy in the design development of a bicycle frame made from rattan. In the process of designing a bicycle frame as a structure, strategies are needed: determining the geometry of the bicycle, engineering the material of the rattan rodstick and the connection of the rattan frame structure. The material experiment test method is carried out with laboratory tests to determine the quality of rattan. The results of this study indicate that for bicycle geometry adapted to its utility, while the structure is better to use a diamond structure. For the engineering of rattan materials the use of infusion resins is proven to increase the strength of rattan rods-stick up to five hundred percent. Some parts of the bicycle frame still use a metal connection as a locking structure so that the rattan structure can be a good construction of the bicycle design.
\end{abstract}

Keywords - bicycle design, frame structure, rattan frame, rattan infusion

\section{PENDAHULUAN}

Upaya pemerintah dalam meningkatkan daya saing rotan adalah mengarahkan pengembangan produk rotan pada produk yang menyangkut gaya hidup masyarakat. Salah satu produk yang menjadi konsumsi gaya hidup dalam 100 tahun terakhir adalah sepeda. Transportasi darat berupa sepeda kebanyakan menggunakan material logam, namun sudah ada alternatif material yang sudah digunakan seperti kayu, bambu, dan komposit karbon fiber. Penggunaan material rotan untuk membuat sepeda dapat memberikan kebaruan material karena material rotan yang ringan dan mudah dilengkung dapat memberikan kebaruan bentuk dari sepeda itu sendiri. Rancang bangun dan prototyping sepeda rotan adalah salah satu inovasi dan kontribusi peningkatan daya saing material rotan [1], [2], [3], dan [4].

Sistem konstruksi rotan berhubungan erat dengan karakter materialnya yang liat dan lentur. Rotan mengandung lignin relatif kecil apabila di bandingkan dengan kayu keras (hardwood) atau kayu lunak (softwood), dimana lignin berfungsi sebagai pengikat antar sel yang memberi kekuatan pada rotan [5]. Sehingga dapat disimpulkan bahwa rotan tidak sekuat metal sebagai struktur pembentuk rangka sepeda.

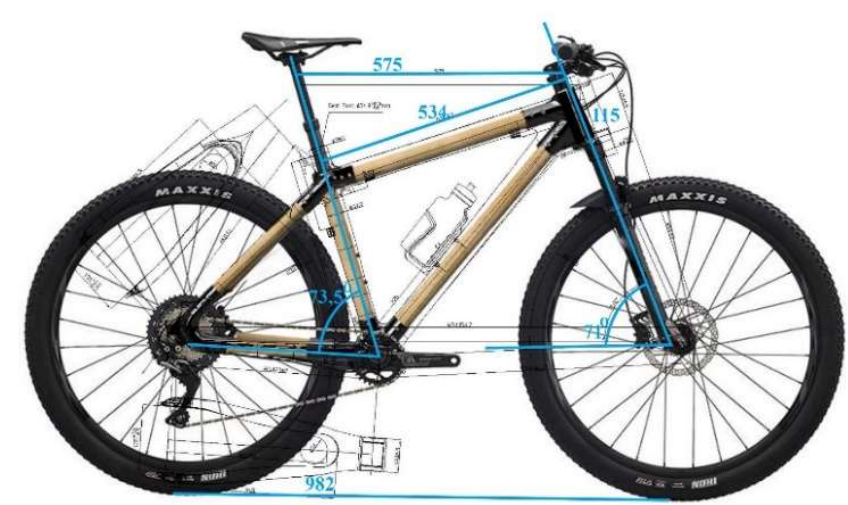

Gambar 1. Visualisasi geometri sepeda rotan dengan struktur batang panjang tanpa bending

Desain rangka pada sepeda adalah faktor utama dalam pemenuhan teknis utilitas sepeda [6]. Pada dasarnya kriteria rangka sepeda yang baik adalah memiliki kekuatan dan kekakuan yang tinggi tetapi ringan dan tahan terhadap korosi 


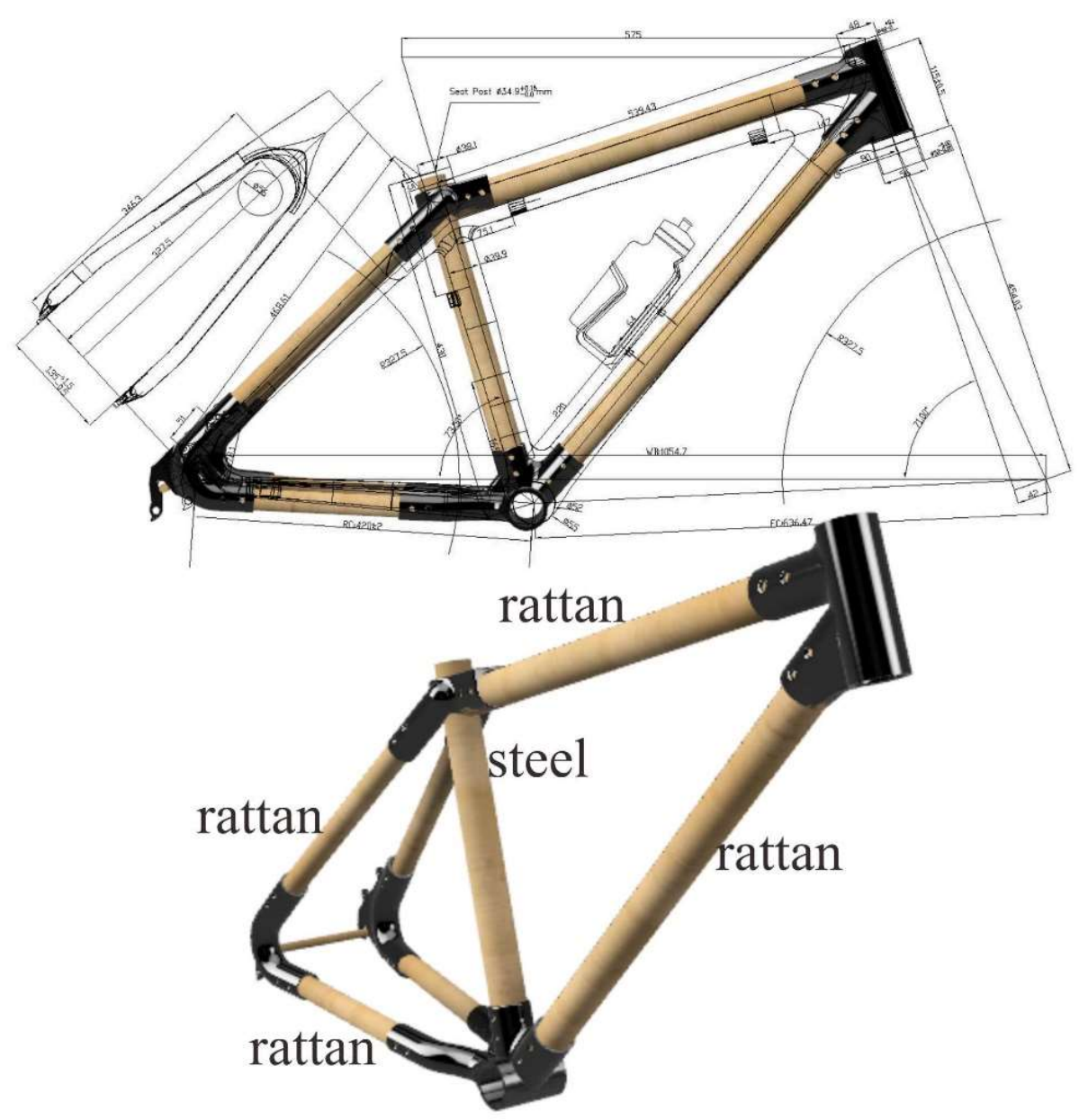

Gambar 2. Anatomi rangka sepeda rotan dengan struktur rotan batang tanpa bending

[7]. Berdasarkan kriteria tersebut rotan adalah salah satu material alternatif yang berlimpah di Indonesia untuk dapat diolah mendekati karakter metal sebagai pembentuk rangka sepeda.

Berdasarkan latar belakang tersebut dilakukan perumusan langkah dalam rekayasa material rotan sebagai struktur pembentuk desain rangka sepeda. Permasalahan yang diangkat selanjutnya adalah bagaimana cara meningkatkan kekuatan rotan sebagai batang utama pembentuk struktur sepeda hingga selanjutnya sepeda memiliki kriteria dapat kokoh dikendarai. Penelitian ini menitik beratkan pada uji batang rotan sedangkan prototyping diuji dengan usability testing.

\section{METODE}

Masyarakat kian bergaya dengan sepeda entah yang diperoleh secara instan dari ragam jenis sepeda hingga penggayaan yang dibangun dengan mengkostum sepedanya. Kostum sepeda dapat berupa atribut produk, fitur atau aksesori estetis produk [8]. Salah satu atribut sepeda yang terkait dengan utilitas sepeda adalah desain rangka, terlebih lagi rangka sebagai struktur utama sepeda haruslah kuat dan aman untuk dikendarai .

Untuk mendapatkan desain rangka sepeda rotan yang memiliki kekuatan dan layak jalan maka metode riset dan eksperimen dilakukan dalam 3 (tiga) tahapan dasar sebagai berikut:
1. Perumusan geometri sesuai dengan struktur sepeda pada umumnya dalam hal ini adalah geometri pengguna dewasa laki laki dengan struktur diamond dengan jenis sepeda hybrid mountain bike

2. Rekayasa material rotan menggunakan metode uji kekuatan dimana kekuatan rotan harus meningkat dari material rotan normal. Dalam pengolahan material dilakukan teknik rotan infus resin.

3. Untuk membentuk struktur rotan dirumuskan bagian rangka sepeda yang masih menggunakan material logam

Sebagai alat ukur keberhasilan dari rekayasa material rotan sebagai struktur sepeda adalah dengan melakukan uji material batang rotan dan uji utilitas setelah prototyping sepeda selesai. Peningkatan kekuatan material rotan sebagai bahan baku struktur diuji dengan uji laboratorium. Peningkatan kekuatan yang signifikan menjadi tolok ukur utama keberhasilan riset ini.

\section{HASIL DAN PEMBAHASAN}

Geometri Sepeda sekaligus Struktur pada Sepeda Rotan Geometri sepeda didapatkan dan disesuaikan dengan kebutuhan utilitas sepeda. Berbeda dengan proses pembentukan rangka sepeda dari logam, rangka sepeda rotan mengikuti karakteristik rotan dimana rotan dengan diameter $30 \mathrm{~mm}$ memiliki kemampuan bending minimum sebesar 180 mm. Geometri sepeda yang didapatkan disesuaikan 

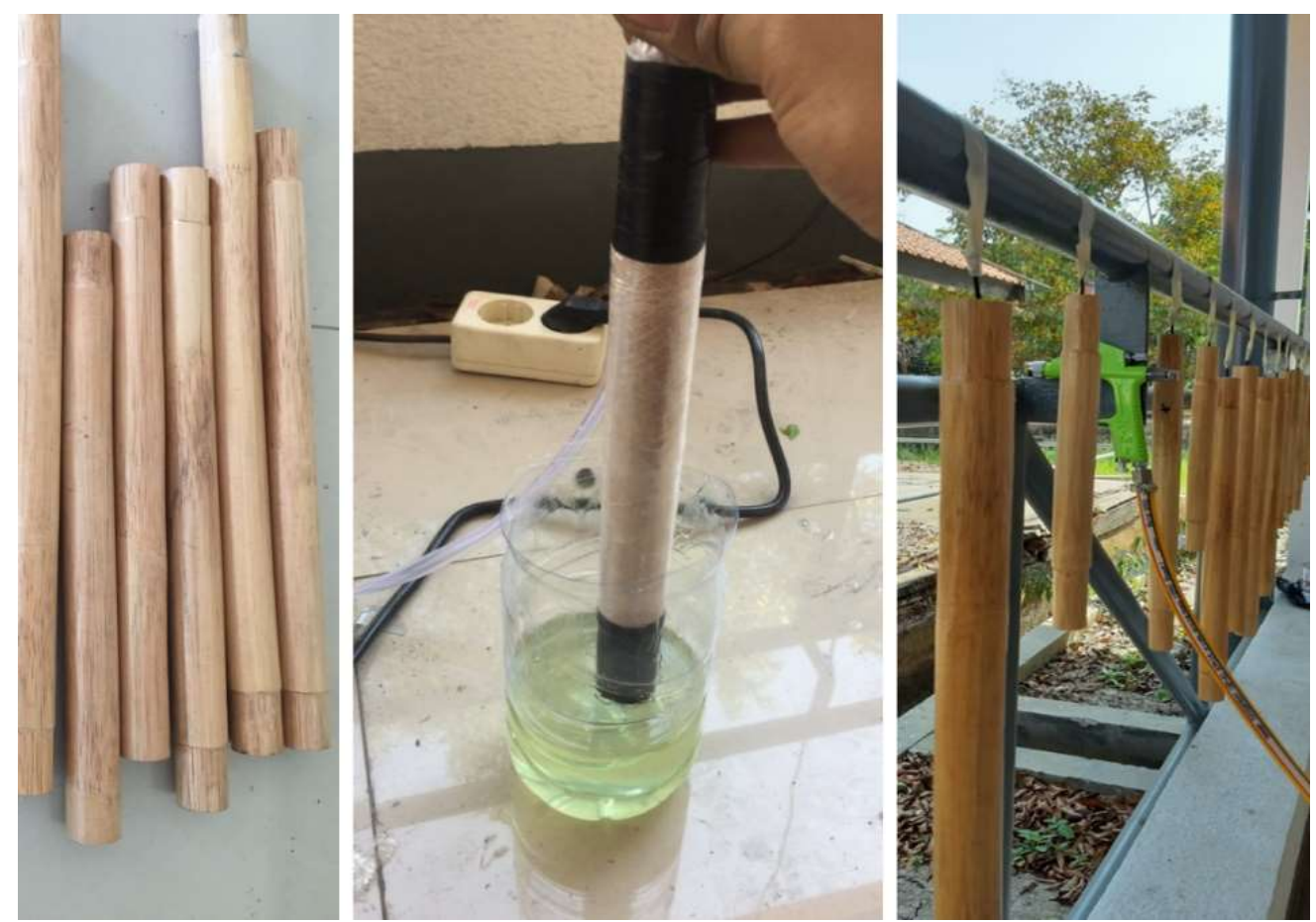

Gambar 3. Proses eksperimen infus resin pada batang rotan

dengan kenyamanan berkendara dengan mempertimbangkan postur berkendara. Posisi badan agak condong, kira-kira. 30 hingga $60^{\circ}$ [9]. Seperti dapat dilihat pada Gambar 1.

Untuk mendapatkan rangka sepeda yang lebih sederhana maka dapat digunakan desain rangka yang tidak memiliki radius bending atau bagian desain yang melengkung dapat digantikan oleh sambungan metal (Gambar 2).

\section{Rekayasa Material Rotan dengan Rotan Resin}

Treatment material rotan dengan matrik resin ini bertujuan untuk meningkatkan mechanical properties dari rotan batang (Gambar 3).

Treatment dilakukan dengan memanfaatkan serat alami yang ada didalam rotan sebagai bahan penguat dan pengikat resin sehingga terbentuk rotan komposit. Pengujian 3 point bending dilakukan untuk mengetahui kekakuan rotan, yaitu kemampuan rotan untuk menahan perubahan bentuk atau lenturan yang terjadi yang dinyatakan dalam MOE. Pengujian dilakukan dengan melakukan perbandingan dari material rotan normal dan rotan hasil (Gambar 4).

Ukuran dan tata cara pengujian lentur rotan menggunakan ASTM D143-94 untuk kayu berukuran kecil dan bebas cacat yang dimodifikasi karena tata cara pengujian lentur rotan secara khusus belum ditemukan baik dalam buku teks maupun media publikasi lainnya. Pengujian dilakukan dengan cara memberikan beban di tengah bentang dengan jarak sangga $28 \mathrm{~cm}$ menggunakan mesin uji UTM [10]. Grafik hasil pengujian dapat dilihat pada Gambar-gambar 5, 6 , dan 7 .

Berdasarkan pengamatan secara visual, dapat dikatakan bahwa rotan infussion resin grade $A$ mengalami permukaan gembos paling kecil yaitu $15 \mathrm{~mm}$, dan rotan normal (paling kanan) mengalami permukaan gembos $40 \mathrm{~mm}$.

Kesimpulan dari Gambar 7 dapat dilihat bahwa untuk rotan normal tanpa treatment memiliki MOE sebesar 54,074.93 $\mathrm{kg} / \mathrm{cm} 2$. Sedangkan treatment rotan dengan resin grade $A$ memiliki peningkatan MOE paling besar, mencapai angka 266,293.94. Hal ini berarti rotan dengan treatment adalah lebih kaku dan teguh daripada rotan normal, dengan peningkatan sebesar 5 kali nilai normal.

\section{Integrasi Material Rotan dengan Material Pembentuk Struktur}

Konstruksi rangka sepeda dengan struktur batang rotan tanpa bending yang sesuai adalah menggunakan konstruksi tertutup dengan struktur diamond. Tiap batang panjang dikunci dengan sambungan metal yang terbuat dari metal sebagai kekuatan tarik dan tekan. Sambungan pada rangka sepeda ini memiliki istilah lug. Syarat kekuatan integrasi rotan pada struktur rangka sepeda adalah tidak bergerak dan harus menetap. Untuk memaksimalkan sambungan ini dapat digunakan dua alternatif kuncian yakni dengan power plug nut atau dengan di lem besi (Gambar-gambar 8, 9, dan 10).

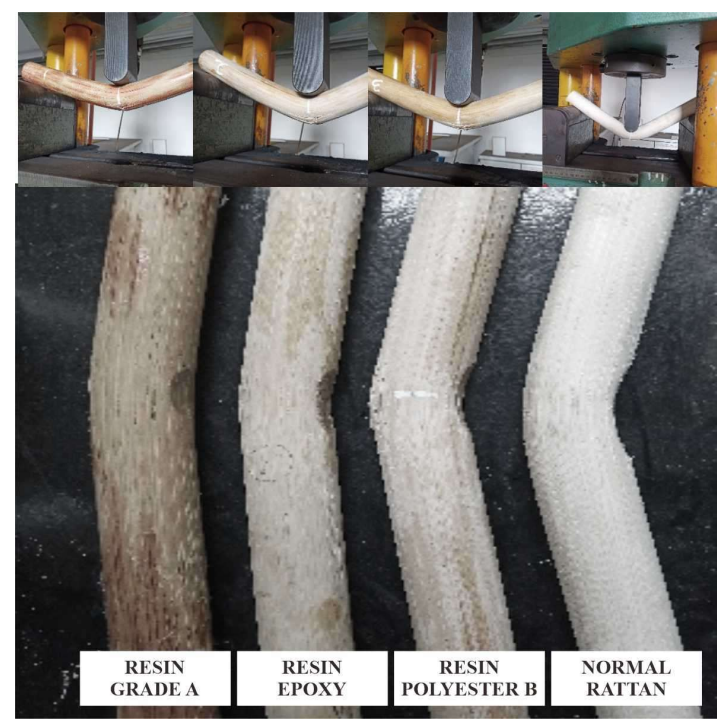

Gambar 4. Visualisasi hasil uji material batang rotan dengan treatment olah material yang berbeda (infusion resin grade A, epoxy resin resin polyester B, dan rotan normal). 


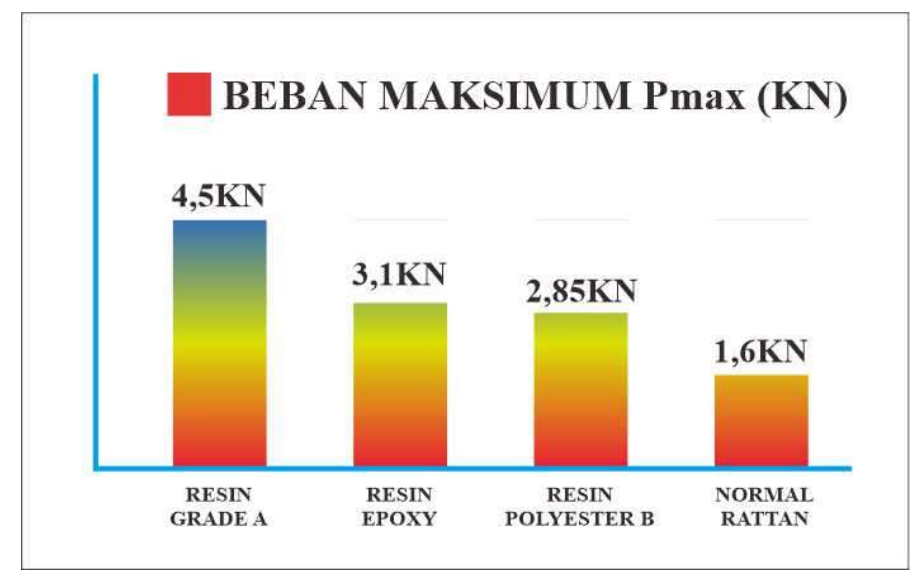

Gambar 5. Grafik hubungan antara jenis resin dan beban maksimum hasil uji bending.

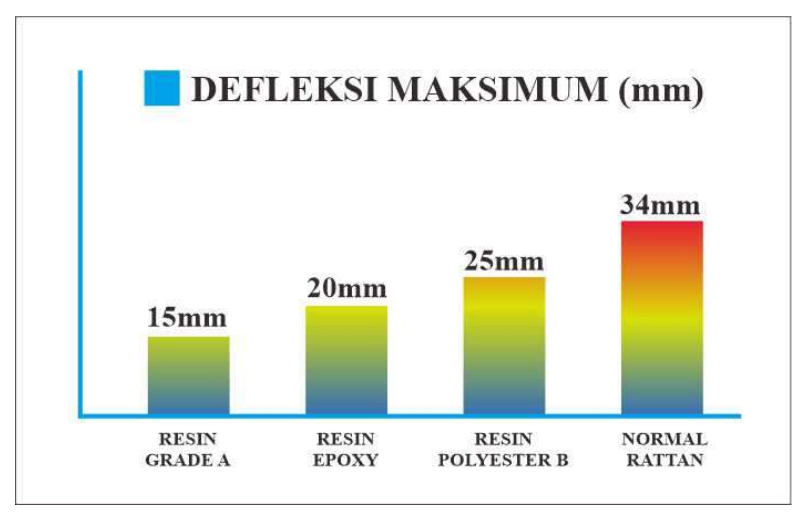

Gambar 6. Grafik hubungan antara jenis resin dan defleksi maksimum hasil uji bending.

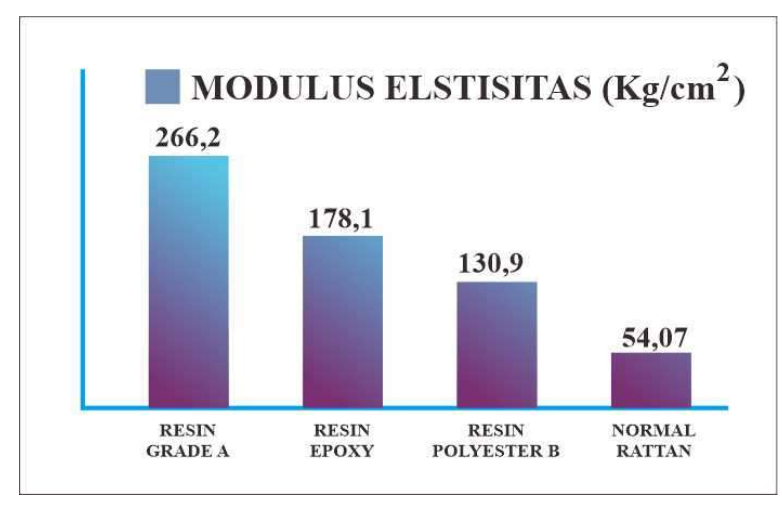

Gambar 7. Grafik modulus elstisitas hasil uji.

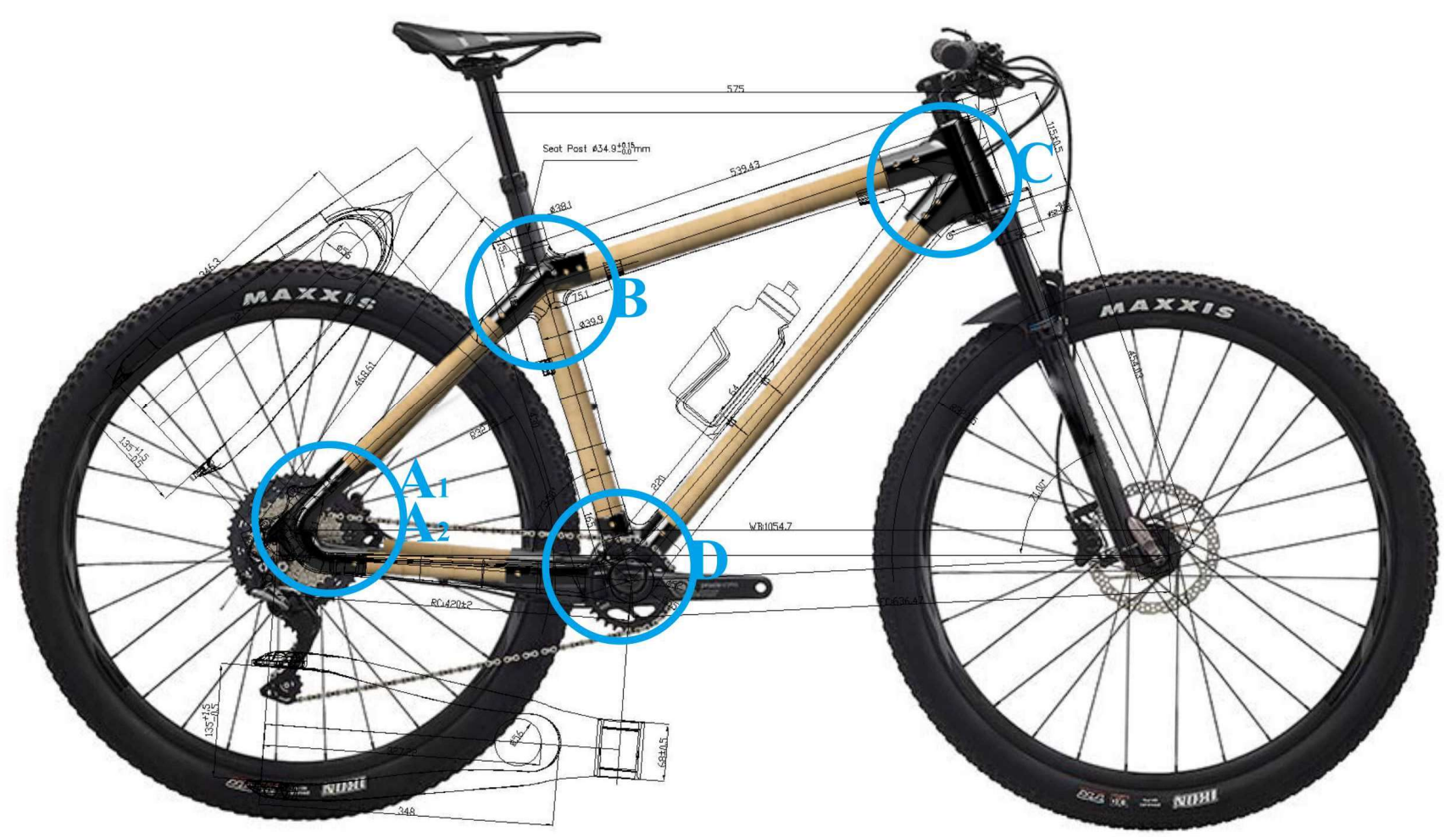

Gambar 8. Penentuan sambungan metal pada struktur rangka sepeda rotan. 


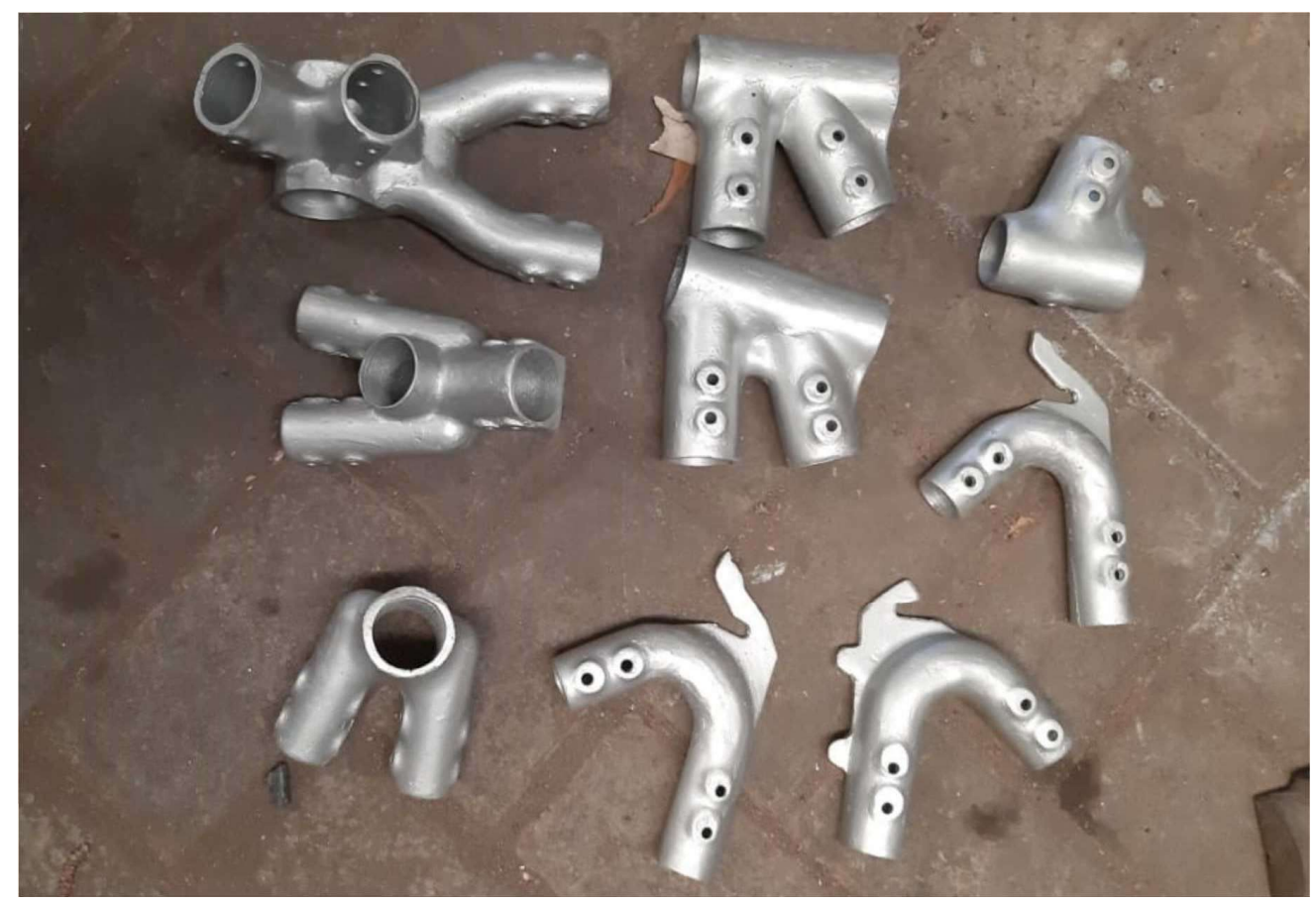

Gambar 9. Sambungan metal pada struktur rangka sepeda rotan.
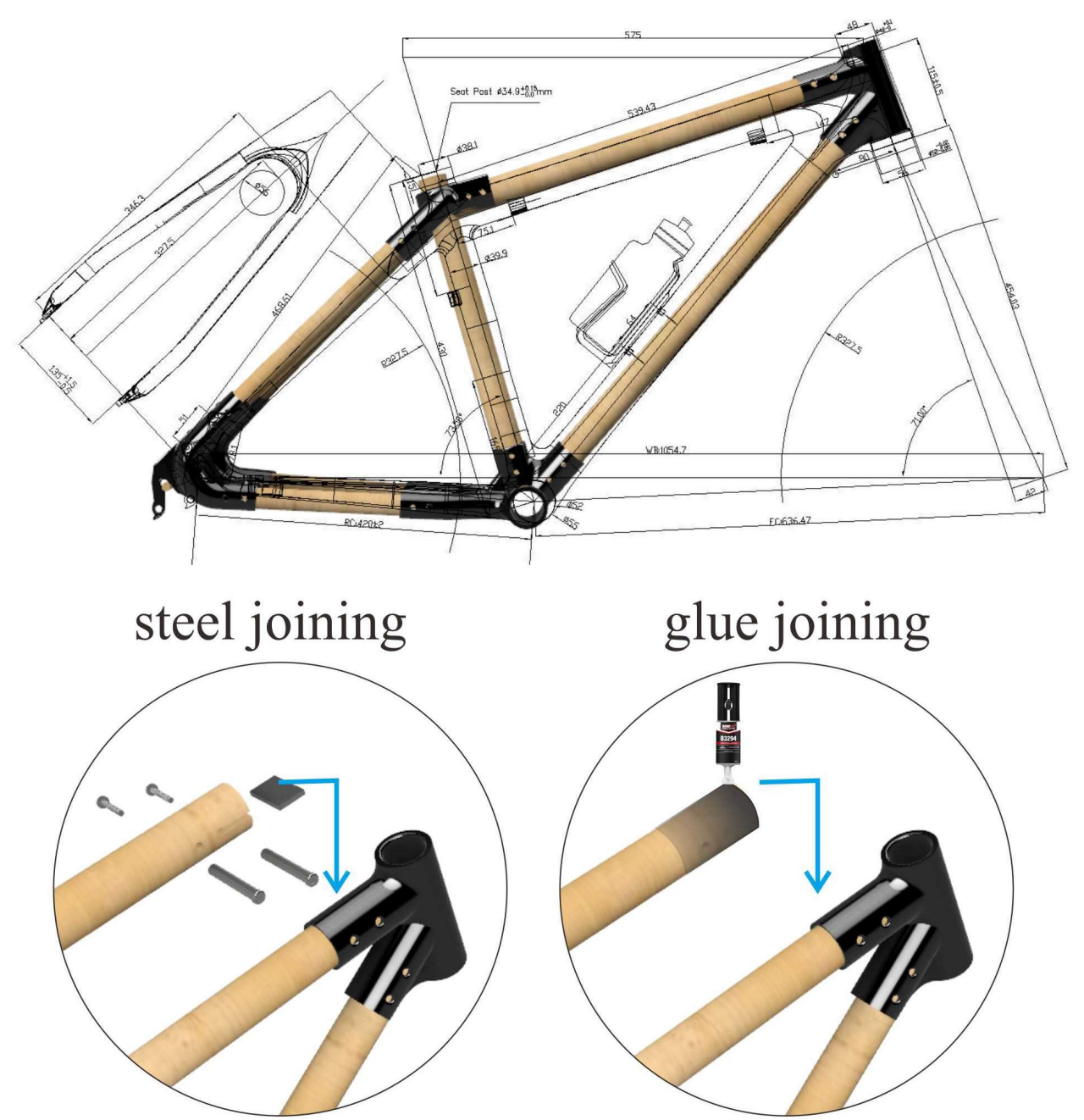

Gambar 10. Visualisasi jenis sambungan antara metal dengan rotan. 


\section{KESIMPULAN}

Rancang bangun dan prototyping sepeda rotan adalah salah satu inovasi dan kontribusi peningkatan daya saing material rotan. Oleh karena itu treatment rattan resin dapat menjadi solusi sebagai cara peningkatan kekuatan batang rotan sebagai struktur rangka sepeda. Visualisasi desain sepeda dengan rotan resin ditunjukkan pada gambar 11 .

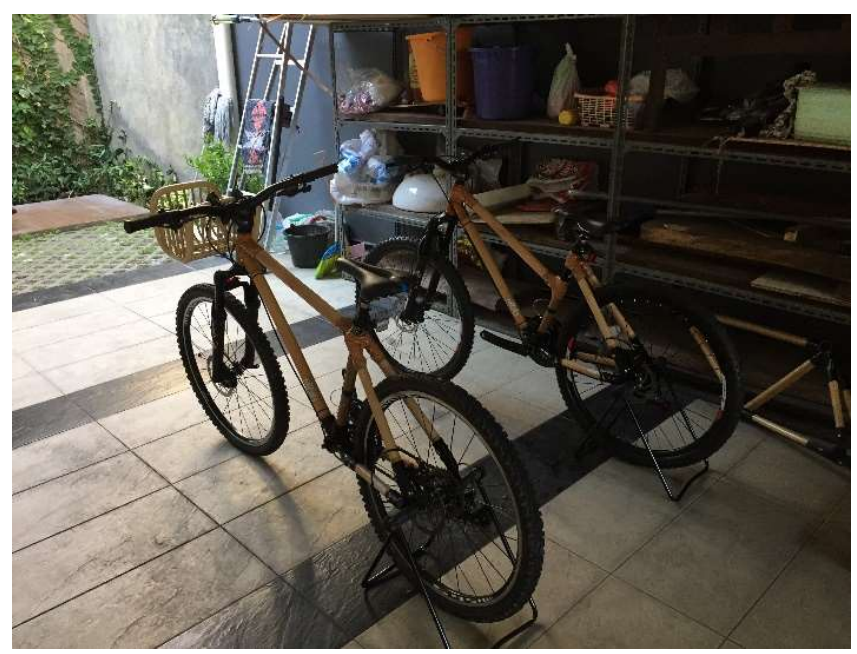

Gambar 11. Prototyping sepeda rotan.

Penggunaan material rotan sebagai struktur pada desain sepeda harus memperhatikan aspek kekuatan dan karakter rotan. Rotan yang memiliki karakter lentur dapat direkayasa menggunakan resin dengan teknik inffusion. Dalam hal ini kekuatan rotan akan bertambah 5 kali lipat. Sedangkan untuk mempertahankan kekuatan struktur pembentuk rangka sepeda maka integrasi sambungan struktur haruslah tidak bergerak, dalam hal ini dapat dikunci menggunakan sistem sambungan khusus maupun dengan lem perekat besi yang kuat. Adanya celah pada integrasi struktur menyebabkan patahan vertikal pada rotan yang sekaligus membahayakan untuk dikendarai. Oleh karena itu rangka sepeda sebagai bagian utama dari sepeda harus benar benar sempurna dalam hal geometri, material maupun integrasi strukturnya.

Pada penelitian ini tahapan uji material sebatas uji kekuatan sederhana yang membandingkan peningkatan kekuatan pada rotan normal. Perlu adanya uji lanjut pada prototyping sepeda terkait dengan durability sepeda saat digunakan di jalan termasuk uji kekuatan berdasarkan perjalanan waktu.

\section{DAFTAR PUSTAKA}

[1] Arie Kurniawan, "Laporan Akhir Inovasi - Desain Sepeda Rotan", (Institut Teknologi Sepuluh Nopember, 2019)

[2] M. Ashby, K. Johnson, "Materials and design, the art and science of material selection in product design" (Butterworth Heinemann, Oxford, UK, 2007)

[3] N. Cross, "Engineering Design Methods, Strategies for product design", Second Edition (John Wiley \& Sons Ltd, Baffins Lane, Chichester, West Sussex, PO19, England, 1998)

[4] H. Christians and A. Bremmer, "Applied ergonomics", 29, 3, 201-211 (1998)

[5] O. Rachman and Jasni, Rotan Sumberdaya, Sifat Dan Pengolahannya. 2013.

[6] Dudy Wiyancoko, "Desain Sepeda Indonesia" (Jakarta, Kepustakaan Pupuler Gramedia, 2010)

[7] Ahmad Yakub, Djoko W, Anwar Ilmar R, “ Optimasi Desain Rangka Sepeda Berbahan Baku Komposit Berbasis Metode Anova" (Jurnal Teknologi, Universias Muhammadiyah Jakarta, 2016)

[8] Arie Kurniawan, Dudy Wiyancoko, Ruly Darmawan, "Bergaya dengan Sepeda : Kajian Fenomena Sepeda sebagai Salah Satu Alat Gaya Hidup Masyarakat" (Jurnal Desain Idea, Institut Teknologi Sepuluh Nopember Surabaya, 2013)

[9] Arie Kurniawan, “ Laporan Akhir Calon Perusahaan Pemula Berbasis Teknologi : Produksi dan Pemasaran Sepeda Rotan" (Kemenristekdikti, CPPBT, 2019 